\title{
The Question of Conation in Action Theory
}

Robert Good

Rider College

In some recent and most interesting articles, Myles Brand argues that intending has an exclusively conative feature. This conative feature is said by Brand to be non-cognitive and to be that aspect of an episode of intending which moves an agent to act. Brand alleges that the conative feature of intending must be included in any satisfactory answer to what he calls the fundamental question in action theory: what characteristics must a mental event possess in order to be the proximate cause of action? Brand contends that no philosophical theory of the relation between intending and acting has been offered which includes the conative feature of intending as an element. Therefore, he thinks that no philosophical theory of the relation between intending and acting has answered the fundamental question in action theory. I shall argue, however, that one contemporary theory of the relation between intending and acting does contain an account of the conative feature of which Brand speaks. I shall submit that Hector-Neri Castañeda's theory of the relation between intending and acting provides an answer to the fundamental question in action theory.2

Brand's identification of a conative component of intending is best understood in light of the recent history of Causal theories of action. Bascially, a Causal theory is one which holds that intentional action is caused by a preceding mental event of a particular kind. Recent interest and developments in such theories owe much in impetus to the work of Donald Davidson whose version of the Causal theory holds that the mental event causing action is the combination of a pro-attitude toward actions of a certain kind and the belief that such actions can be performed." A proattitude, according to Davidson, can be a desire, a wanting, an urging, a prompting, and numerous other things, such as a moral view, an aesthetic principle, a private goal, etc. Davidson's account, however, has been severely criticized. Wilfrid Sellars, for example, finds Davidson's theory objectionable on the grounds that it does not pinpoint the type of mental event that has action as its effect." Sellars thinks that the term 'pro-attitude' does not identify with 
sufficient specificity the mental event that causes action. To correct Davidson's undersight, Sellars proposes that the mental event causing action is an agent's intending to do something here and now. For example, on Sellar's view, when an agent picks up a newspaper, he or she forms the intention to pick up the newspaper here and now, and this episode of intending on the part of the agent is the mental event that causes his or her picking up of the newspaper. In his appraisal of Causal theories, Brand notes that Sellars' version fails to provide a complete account of the relation between intending and acting. because it says nothing about the internal structure of an intending to do something here and now. Therefore, Brand finds promising the work of Castañeda, whose version of the Causal theory explores the intermal structure of episodes of intending.

Expanding on Sellars' view, Castañeda theorizes that an episode of intending to do something here and now has a special sort of thought-content as its object. Castañeda calls this thought-content a firstperson practition. Endorsingly thinking a first-person practition constitutes, for Castafieda, an episode of intending to do something here and now and triggers the action mechanisms involved in performing the action. To lllustrate, suppose that I jump intentionally. Castañeda's view is that my jumping intentionally proceeds from my focusing upon I (i.e. me, myself) and upon the act-type jump. This focusing generates in my mind the thought-content $* I$ (to) jump*, a first-person practition. The ' $(\text { to })^{\prime}$ in the notation of the firstperson practition represents what Castafieda calls the practical copula which connects subject and predicate in an actional, as opposed to a contemplative, way. Next, and most crucially, my thinking endorsingly *I (to) jump* triggers the action mechanisms involved in my jumping. It is important to see that Castañeda's theory does not recognize the mere generation of a first-person practition to constitute an episode of intending. Only the endorsing-thinking of a firstperson practition is said to be sufficient to effect intentional action.

Brand argues that Castañeda's account, like Sellars' account, fails to provide a complete description of the mental event that causes action. He alleges that Castañeda has analyzed the relation between intending and acting solely in terms of the purely cognitive event of focusing. In defense of this charge, Brand asks us to imagine that an agent is in a room in which he has the opportunity to jump up and touch the ceiling. Brand points out that even though the agent may focus on himself performing that action, he still may not actually jump up and touch the ceiling. This fact is said to show that focusing on oneself performing a particular action is insufficient to bring the 
action about, that, in addition to the cognitive activity of focusing, there must be a moving of the agent to act. Consequently, Brand insists that the mental event that causes action must include a self-pusling aspect that is the proximate cause of action. This selfpushing aspect is referred to by Brand as the conative component of intending. Brand claims that although Castañeda's more detailed description of the relation between intending and acting renders his Causal theory an improvement over previous versions, it, too, is incomplete in that it omits this essential conative element. Therefore, Brand thinks that Castañeda has not answered the fundamental question in action theory.

Brand's charge that Castañeda's theory omits the so-called conative component of intending is mistaken. Brand is surely correct to point out that merely focusing on oneself performing a particular action is not sufficient to bring the action about and that some sort of self-pushing or moving of the agent to act must also be involved in the mental event that causes action. This fact, however, is clearly accommodated by Castañeda's theory in its distinction between the generation of a first-person practition, in which focusing is involved, and the endorsing-thinking of a first-person practition, which initiates action. On Castafieda's account, an intentional action depends not only on the agent's focusing on himself doing the action he intends, but also on the agent's endorsingly thinking the particular first-person practition that is generated out of his focusing. Without the endorsing-thinking of a first-person practition, there is no episode of intending and, therefore, no intentional action, as far as Castañeda's theory is concerned. However, with the endorsing-thinking of a first-person practition, action is triggered, according to Castafieda, unless some prohibitive force is operative. That is, the endorsingthinking of a first-person practition is, in Brand's terms, a self-pushing or a moving of the agent to act in that it triggers the action mechanisms involved in bringing the intended action about. Thus, Castarieda does not analyze the relation between intending and acting solely in terms of the cognitive event of focusing, as Brand claims. Rather, the more crucial element in his theory is the endorsing-thinking of a firstperson practition, which satisfies Brand's demand that an account of the relation between intending and acting include a conative feature. Brand attends only to the mechanism of focusing that Castañeda describes and overlooks the endorsing-thinking that Castar̂eda also claims to be occurring in episodes of intending. Castañeda's theory clearly recognizes that no amount of focusing, alone, is sufficient to effect action, that only the endorsing-thinking of a first-person practition with its moving of the agent to act is so suf- 
ficient. Castanfeda has, therefore, provided an answer to the fundamental question in action theory.

My thesis in this paper is important to the direction of future work in action theory. Finding no analysis of the conative feature of intending present in contemporary philosophical theories of action. Brand has decided to look to motivational psychology for help. His conviction is that the time has come for "the philosophy of action and motivational psychology to proceed in concert." " Brand finds promising the work of .John Atkinson and David Rirch. ${ }^{7}$ They presuppose that a peron has a large number of tendencies for activity. A person does a certain activity when his tendency to do that activity is dominant and continues in that activity until a time when another tendency becomes domimant. Atkinson and Bilch set themselves to explain what causes a person to change from one activity to another. This is the problem of motivation. They allow that mental events can strengthen the instigatory force to perform a certain activity. " Their view is that it is the content of a mental event which strengthens the instigatory force to perform a certain action. Their example is that the content of the thought of eating steak strengthens the instigatory force to eat steak.

Brand thinks that Atkinson and Birch's work is promising for philosophical action theorists to investigate because it may provide a clue regarding the nature of the conative feature of intending. Yet, he strongly objects to their view that the content of a thought can strengthen the tendency to act. Merely contemplating a thought-content, according to Brand, does not move a person to act.

I suggest that there is no need for philosophical action theorists to venture into motivational psychology in order to find an account of the conative feature of intending. Brand, himself, does not find a satisfactory account in motivational psychology 1iterature. What is more, if my thesis is correct, an account of the conative feature of intending has already been offered in philosophical action theory by Castañeda.

My thesis is also important to understanding the distinctive nature of Castafieda's action theory. Traditionally. the objects of intending episodes have been taken to be propositions.' A problem with this view is that one can endorse a future-tense proposition (e.g. 'I will jump') without jumping. Endorsing a proposition does not, by itself, produce action. In other words, an agent can think of doing an action and not do it. Castahieda, however, unlike his counterparts who hold that the objects of intending episodes are propositions, does explain the causality that is operative in intentional actions. He does so by theorizing that the objects of intending episodes are practitions, 
not propositions. While an agent can endorse the proposition 'I will jump' without jumping, an agent cannot endorse the practition $\star I$ (to) jump* without jumping, unless something goes wrong. Castañeda analyzes the thinking causality involved in intentional action, that which effects the transition from the mental to the physical, as the endorsement of the special thought-content of intending episodes." Practitions, by their nature, when endorsed, produce action. This unique idea should command the attention of those working in action theory because it does, indeed, provide an answer to the fundamental question in action theory. 11

\section{NOTFS}

'Myles Brand, "The Fundamental Question in Action Theory." Noûs XIII (1979). pp. 131-151, and Myles Brand, "philosophical Action Theory and the Foundations of Motivational Psychology," in Action and Responsibility, Michael Bradie and Myles Brand, eds., (Bowling Green, Ohio: 1980), pp. 1-19.

${ }^{2}$ Castañeda presents his theory of the relation between intending and acting in his Thinking and Doing (Dordrecht, Holland: 1975).

'Donald Davidson, "Actions, Reasons, and Causes," Journal of Philosophy LX (1963), pp. 685-700.

"Wilfrid Sellars, "Actions and Events," Noûs VII (1973), pp. 179-202.

'The 'me, myself' is present to signal that I think of myself in the first-person way. For Castañeda, the 'me, myself' is a quasi-indicator which represents a first-person indexical reference by me to myself. See Hector-Neri Castañdeda, "Indicators and QuasiIndicators," American Philosoplical Quarterly 4 (1967), pp. 85-100. The issue of first-person indexical reference has been addressed a lot lately, e.g., David Lewis, "Attitudes De Dicto and De Se," The Philosophical Review $\frac{1}{87} \frac{\text { Dicto }}{(1979), ~ p p . ~ 5 \frac{13}{13}-5 \overline{43} ; " \text { John }}$ Perry, "The problem of the Essential Indexical." Nous XIII (1979), pp. 3-21; and steven Boer and William Lycan, "Who, Me?," The Philosophical Review 89 (1980). pp. 427-466.

"Myles Brand, "Philosophical Action Theory and the Foundations of Motivational Psychology," in Action and 
Responsibility, Michael Bradie and Myles Brand, eds.. (Bowling Green, Ohio: 1980), p. 1.

'See John Atkinson and David Birch, The Dynamics of Action (New York: 1970).

'David Birch, John Atkinson, and Kenneth Bongort, "Cognitive Control of Action," in Cognitive Views of Human Motivation, B. Weiner, ed., (New York: $\overline{1974}), \overline{\text { p. }}$ 80 .

'Roderick Chisholm labels as 'traditional' the view that propositions are the objects of intending episodes. See Roderick Chisholm, "Castañeda's Thinking and Doing," Noûs XIII (1979), Pp. 385-396.

10lofor an interesting, critical discussion of Castañeda's version of the Causal theory of action. see Donald Gustafson, "Castañdeda's Intentions: A Critical study of Castañeda's Thinking and Doing," Synthese 44 (1980), pp. 247-284.

"I would like to thank Hector-Neri Castañeda with whom I had many fruitful discussions of action theory during 1980-81 when I held a seminar fellowship awarded by the National Endowment for the Humanities. I would also like to thank the NEH for its financial support during that productive year at Indiana University, Jacqueline Nelson for many helpful observations about action theory. and two anonymous reviewers for Auslegung for their valuable comments on an earlier version of this paper. 